\title{
Professionalization in healthcare chain
}

1 Andrej Starc

1 Faculty of Health Sciences, Chair of Public Health, University of Ljubljana, Zdravstvena pot 5, 1000 Ljubljana, Slovenia

\section{Abstract

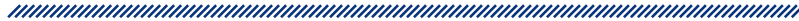

Background: Several elements influence the process of professionalization. The focus is on the process of professionalization in the healthcare chain. A special emphasis proportion was given to the field of nursing and its gradual transition to the profession. During the transition process endogenous and exogenous environment act as elements which should be identified.

Methods: Data were analysed using quantitative and qualitative methodology. A quantitative part involved descriptive statistics, contingency analysis and ordinary least squares and multivariate linear regression with and without control variables, both based on indexation. The qualitative part consisted of the analysis of the data collected through open-ended questions and semi-structured interview. An adjusted questionnaire was designed.

Results: Attributes into the process of professionalization are present in nursing professionals aged more than 51 years with more than 26 years of working experience, employed at primary level of healthcare. The acquisition of new knowledge represents the contribution to their human capital and contemporaneously raises their expert power as well. Lifelong learning, nursing professional autonomy and specific knowledge in nursing as an endogenous and exogenous factors indicate statistically significant positive impact. The analysis identified that ethics in nursing had only marginal statistically significant positive impact in the process of nursing professionalization.

Conclusions: The identification of endogenous and exogenous elements allows additional planning as well as research into the practice and quality of care in general.

Keywords: process of professionalization, healthcare, healthcare chain, human capital

Article received: 16.04.2016.

Article accepted: 26.10.2016.

Corresponding author:

Asst. Prof. Andrej Starc, PhD, BSc (RN), BSc. Ed. Faculty of Health Sciences, Chair of Public Health, University of Ljubljana

Zdravstvena pot 5, 1000 Ljubljana, Slovenia.

Phone: +38613001111

Fax: +35613001119

E-mail: andrej.starc@guest.arnes.si 


\section{Introduction}

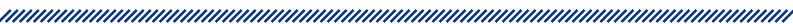

The process of professionalization can be defined as a strategy of position control in the market. Professionalization can be understood as a collective professional control in the market rather than just a list of characteristics ${ }^{1}$. At the global level the literature identifies three key critical dimensions of professionalization, that is, knowledge, power and ethics ${ }^{2-3}$.

With respect to the above key dimensions, only few professional groups achieve a high level of professionalization.

This is mainly due to the fact that professional occupations take up resources and thus prevent access other occupations from accessing them. On the other hand, several occupations failed on this path to enhance their own power, prestige and influence. The literature defines the concept of nursing as semi-profession, due to the non-separation of the basic scientific knowledge and a greater tendency to emphasize the skills, or inadequate theoretical knowledge and low power of selfregulation ${ }^{3-6}$.

Our research considered professions as a decentralized form of social control and the action of professional group members based on knowledge, power and ethical values. We focused on nursing experts with the aim to identify nursing professionalization elements in Slovenia. The basic thesis of our research is that in Slovenia nursing is developing gradually into a profession by achieving some significant professionalization attributes.

In healthcare organizations nursing experts should be understood as knowledge workers, characterized by a combination of autonomy and responsibility for quality and safe treatment of most complex patients' conditions ${ }^{7}$. They represent the thinking human capital, since during education and lifelong learning their active knowledge increases and regularly recombines, thus making their exploitation and recombination of existing knowledge more effective. When developing knowledge strategy, we define nursing experts as "bimodal learners", i.e. simultaneous knowledge creators and knowledge exploiters respectively ${ }^{8-15}$.

\section{Methodology}

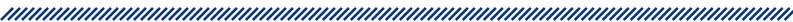

We used a quantitative and qualitative methodology. The sample included three groups. The first group were employees in nursing and the second group were members of nursing management, both groups had in common the same inclusion criteria. i.e. at least postsecondary education in the nursing field. The third group were members of top management of healthcare organizations at the first, second and third level of healthcare system. The inclusion criteria for healthcare organizations were based on ten regional units (RU) in Slovenia. In every RU one healthcare organization at the first and one organization at the second level of healthcare system were chosen by random. The exception was made in the RU Ljubljana where the Health Centre of Ljubljana was chosen at the primary level, the hospital of dr. Petra Držaja at the second and the Medical Centre of Ljubljana and the Oncology institute at the third level. Data were collected from March to August 2008. The data was analysed by the computer program SPSS 13.0. The sample size was 633 . The sample realization was $11,97 \%$ and responsiveness was $41,10 \%$. For the collection of data we developed special measuring instruments - we used a validated questionnaire and a semistructured interview. Data for the questionnaire were collected from nursing practitioners and from nursing management - the micro level of healthcare system. Secondly, we used the semi-structured interview to collect data from high levels of healthcare organizations - meso level of healthcare organizations. Thirdly, the comparative analysis of statistical and dynamical specifics of occupational group are at meso level.

The questionnaire included 69 questions (66 close and 3 open questions). Besides the demographic characteristics, education and learning process of the sample, the questionnaire included 5 scales which measured the professionalization (Cronbach alfa coefficient $=\alpha$ ) $(\alpha=0,75)$, autonomy in nursing $(\alpha=0,52)$, lifelong learning in nursing $(\alpha=0,88)$, knowledge in nursing $(\alpha=0,87)$, professional power in nursing $(\alpha=0,88)$ and ethics in nursing $(\alpha=0,64)$.

Indexes were calculated as the arithmetic mean value of the considered argument. The reliability of individual indexes was calculated based on the method of factor analysis. 


\section{Results}

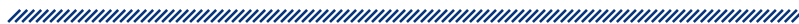

\subsection{Quantitative analysis}

At the micro and mezzo level of analysis, a combination of quantitative and qualitative research was used in the present research. For the quantitative part a validated questionnaire was employed. For the qualitative part, a questionnaire consisting of open-ended questions was used. The sample consisted of nursing experts at the primary, secondary and tertiary level of healthcare and members of top management of healthcare organizations. The semi-structured interviews were conducted with members of the top management and professional management of healthcare organizations.

The majority of the respondents $(44.9 \%, n=284)$ are employed at the tertiary level of healthcare; $30.6 \%$ ( $n=$ $194)$ at the primary and $22.9 \%(n=145)$ at the secondary healthcare level $(n=145)$. A large majority of the respondents were female $(93.7 \%, n=546, N=15,843)$; the prevalence of women is statistically significant at all levels of healthcare $(M=1.06, S D=0.244, p=0.018$, $\chi 2=8.084$ ), indicating a strong feminization of nursing. The group aged from 41 to 50 years dominates significantly only at the primary healthcare level $(n=572$, $M=2.37, S D=0.982, p=0.000, \chi 2=37,883)$, while at the secondary and tertiary level younger respondents prevail (from 31 to 40 years). With respect to working years, the group of more than 26 years of work experience dominates significantly at the primary level ( $\mathrm{n}$ $=572, \mathrm{M}=3.66, \mathrm{SD}=1.845, \mathrm{p}=0.000, \chi 2=40.313$ ). At all healthcare levels, the distribution of respondents differs significantly with respect to working years: the group from 6 to 10 years of experience prevails at the secondary level, while the group from 0 to 5 of working years at the tertiary level. As regards the achieved professional degree, the healthcare levels clearly differ, with diploma level education more prevalent at the primary healthcare level. The characteristics of working position/function in Slovenian healthcare organizations is that team nurses dominate $(43.5 \%, \mathrm{n}=250)$. The shares of others are smaller: the ward nurse, head of the clinical/departmental nursing activities (the head of one ward), the head of clinical/departmental nursing activities (the head of several wards) and the head of all clinical/hospital activities (the head of the nursing staff $)(1.0 \%, n=6)(n=575, M=1.87, S D=0.859$, $p=0.109, \chi 2=13.096)$. The distribution of nurse professions with respect to working position/function is rather different at all healthcare levels. Group of ward nurses prevails at the primary and team nurses at the tertiary level ${ }^{16}$.

\subsubsection{Bivariate relationship between indexes and control variables}

\section{Index of professionalization in nursing}

The research findings indicate that the index of professionalization in nursing correlates with the number of nursing experts aged 52 and over, with more than 26 years of work experience, working at the primary level of healthcare in a position of the head of one ward, and who attended education and learning programmes more than 5-times/year and agreed that the acquisition of knowledge represents a contribution to the healthcare organization at the same time.

\section{Index of knowledge in nursing}

The index of knowledge in nursing correlates with nursing experts aged 41 to 50 years of age at the primary level of healthcare, in a position of a manager of nursing, and who have attended educational and learning programmes more than 5-times/year and agreed that the acquisition of knowledge represents a contribution to the healthcare organization at the same time.

\section{Index of professional autonomy in nursing}

The index of professional autonomy in nursing correlates to nursing experts at the primary level of healthcare, in a position of the head of several wards, and who have attended educational and learning programmes more than 5-times/year and agreed that the acquisition of knowledge represents a contribution to the healthcare organization at the same time.

\section{Index of lifelong learning in nursing}

The index of lifelong learning in nursing correlates with nursing experts at the primary level of healthcare, who attended educational and learning programmes more than 5-times/year and agreed that the acquisition of knowledge represents a contribution to the healthcare organization at the same time.

\section{Index of professional power in nursing}

The index of professional power in nursing correlates with nursing experts who agreed that the acquisition of knowledge represents a contribution to the healthcare organization at the same time. 
Index of ethics in nursing

This index correlates with nursing experts with more than 26 years of work experience.

The above results lead to a conclusion that nursing experts perceive continuing education and regular upgrading of knowledge as very important, which, at the same time, also contributes to a better functioning of the healthcare organization. The index of professionalization in nursing and the index of professional autonomy in nursing represent a common factor at the level of healthcare organizations. It could also be concluded that nursing experts at the primary level are much more conscious of the significance of professionalization and professional autonomy. More mature nursing experts with considerable amount of clinical experience are better aware of connotation of knowledge and professionalization in nursing.

\subsection{Qualitative analysis}

The data for quality analysis were derived from a questionnaire composed of open-ended questions and through a structured interview (Table 1-4).

\subsubsection{Nursing professional autonomy}

\section{Analysis of negative experiences}

The argument of negative experiences could suggest the absence of autonomy and equal position, derived from nursing professionals themselves.

\section{Analysis of positive experiences}

The main item "What is nursing autonomy?" shows nine (9) categories: knowledge (subcategories: information transfer, autonomy in decision-making, professional knowledge, relation to patients); education; ethical val-

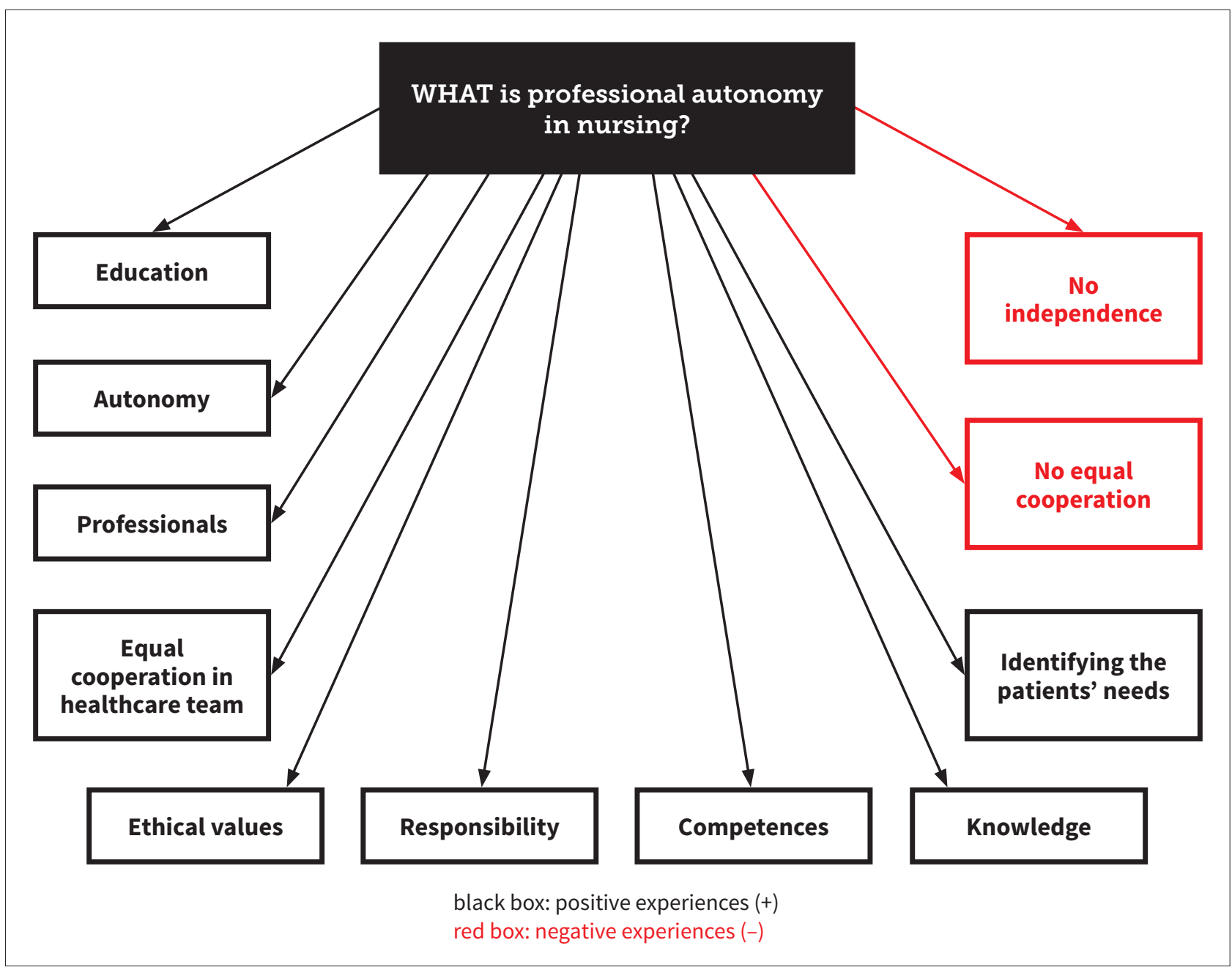

Figure 1. Nursing professional autonomy

Source: Starc, 2011: 241 


\begin{tabular}{|c|c|c|c|}
\hline & $\begin{array}{l}\text { Main } \\
\text { item }\end{array}$ & Categories & Subcategories \\
\hline \multirow{16}{*}{ 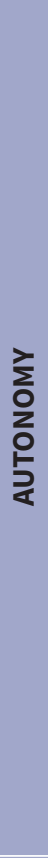 } & \multirow{16}{*}{ 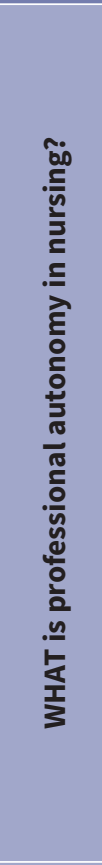 } & \multicolumn{2}{|c|}{ POSITIVE EXPERIENCES } \\
\hline & & \multirow{4}{*}{ knowledge } & information transfer, \\
\hline & & & independent decision-making, \\
\hline & & & professional knowledge, \\
\hline & & & patient treatment \\
\hline & & education & \\
\hline & & ethical value & \\
\hline & & expert & \\
\hline & & $\begin{array}{l}\text { equal (equal member) } \\
\text { cooperation in healthcare team }\end{array}$ & $\begin{array}{l}\text { cooperation in healthcare team, } \\
\text { competences }\end{array}$ \\
\hline & & independence & \\
\hline & & competences & \\
\hline & & identifying patient needs & \\
\hline & & responsibility & \\
\hline & & \multicolumn{2}{|c|}{ NEGATIVE EXPERIENCES } \\
\hline & & no independence & \\
\hline & & no equal cooperation & \\
\hline \multirow{9}{*}{$\begin{array}{l}\text { 方 } \\
\text { o } \\
\text { 인 } \\
\frac{5}{2}\end{array}$} & \multirow{9}{*}{ 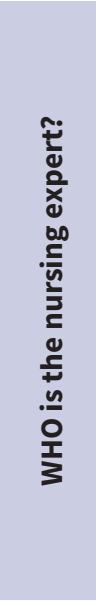 } & \multicolumn{2}{|c|}{ POSITIVE EXPERIENCES } \\
\hline & & competences & \\
\hline & & cooperation with other experts & \\
\hline & & $\begin{array}{l}\text { equal cooperation in the healing and recovery process, } \\
\text { independent decision-making }\end{array}$ & $\begin{array}{l}\text { responsibility, } \\
\text { independent performing }\end{array}$ \\
\hline & & experts/professionals & \\
\hline & & $\begin{array}{l}\text { equal cooperation } \\
\text { (equal member) in healthcare team }\end{array}$ & \\
\hline & & knowledge & $\begin{array}{l}\text { professional knowledge, } \\
\text { ethics }\end{array}$ \\
\hline & & \multicolumn{2}{|c|}{ NEGATIVE EXPERIENCES } \\
\hline & & subordination & \\
\hline
\end{tabular}

ues; expertise; equal (equal member) cooperation in a healthcare team (subcategories: cooperation in healthcare team, competences); autonomy; competences; identification of patients' needs, and responsibility.

The qualitative analysis shows that the nursing professional autonomy is linked to nursing expertise and that it is based on knowledge, competences and equal cooperation in a healthcare team; nursing autonomy refers to an educated and independent nursing expert with the responsibility for his/her work based on ethical values (Fig. 1).

\subsubsection{Nursing expert}

\section{Analysis of negative experiences}

Nursing experts in a healthcare team had no equal position, derived from subsidiary position. 
Table 2. Summary of the results of the qualitative analysis and a list of the categories of the questionnaire - 2nd part

\begin{tabular}{|c|c|c|c|}
\hline \multirow{15}{*}{ 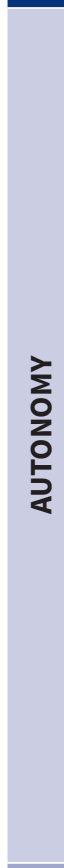 } & \multirow{15}{*}{ 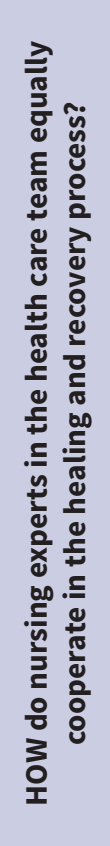 } & \multicolumn{2}{|c|}{ POSITIVE EXPERIENCES } \\
\hline & & jurisdiction & \\
\hline & & knowledge & \\
\hline & & competences & \\
\hline & & independent work in healthcare team & equal expert \\
\hline & & \multirow{2}{*}{ independent performance of nursing procedures } & \\
\hline & & & \\
\hline & & knowledge upgrade & ethics \\
\hline & & cooperation in the treatment process & $\begin{array}{l}\text { benefits, } \\
\text { ethics }\end{array}$ \\
\hline & & independent decision-making & \\
\hline & & \multirow{2}{*}{$\begin{array}{l}\text { equal cooperation } \\
\text { in healthcare team }\end{array}$} & \\
\hline & & & \\
\hline & & \multicolumn{2}{|c|}{ NEGATIVE EXPERIENCES } \\
\hline & & subordinate status & \\
\hline & & no equal cooperation & \\
\hline \multirow{13}{*}{ 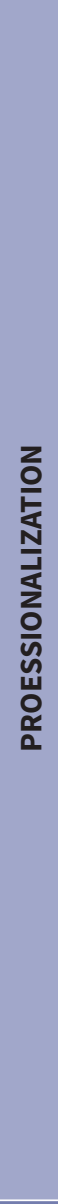 } & \multirow{13}{*}{ 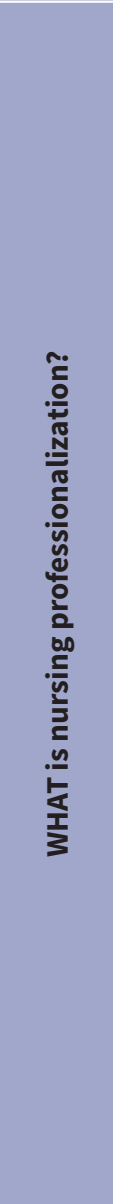 } & \multicolumn{2}{|c|}{ POSITIVE EXPERIENCES } \\
\hline & & lifelong learning & social relationships, \\
\hline & & \multirow[b]{2}{*}{ competences } & quality of work \\
\hline & & & $\begin{array}{l}\text { social needs satisfaction, } \\
\text { autonomy in decision-making, } \\
\text { research, } \\
\text { specialization of nursing experts }\end{array}$ \\
\hline & & \multirow{2}{*}{$\begin{array}{l}\text { acquisition of monopoly } \\
\text { above a certain activity }\end{array}$} & \\
\hline & & & \\
\hline & & acquisition of supervision & $\begin{array}{l}\text { quality of patient care, } \\
\text { ethical values }\end{array}$ \\
\hline & & education & $\begin{array}{l}\text { establishment of standards and rules, } \\
\text { supervision at work }\end{array}$ \\
\hline & & knowledge & $\begin{array}{c}\text { ethical values, } \\
\text { expertise, } \\
\text { social needs satisfaction, } \\
\text { patient satisfaction, } \\
\text { knowledge use at work }\end{array}$ \\
\hline & & acquisition of jurisdiction & acquisition of responsibility \\
\hline & & legal normative & social trust \\
\hline & & education & \\
\hline & & autonomy in nursing & $\begin{array}{l}\text { knowledge in nursing, } \\
\text { cooperation in treatment process, } \\
\text { leadership, } \\
\text { responsibility, } \\
\text { implementation in nursing }\end{array}$ \\
\hline
\end{tabular}


Table 3. Summary of the results of the qualitative analysis and a list of the categories of the questionnaire - 3rd part

\begin{tabular}{|c|c|c|c|}
\hline \multirow{8}{*}{ 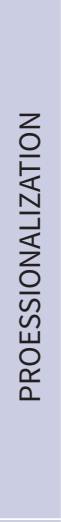 } & \multirow{8}{*}{ 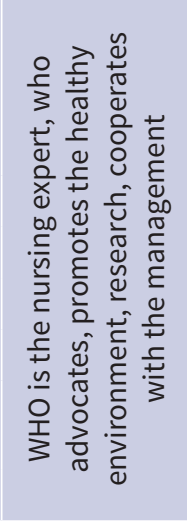 } & \multicolumn{2}{|c|}{ POSITIVE EXPERIENCES } \\
\hline & & independent nursing performance & $\begin{array}{c}\text { patient needs, } \\
\text { independent management and administration of } \\
\text { nursing }\end{array}$ \\
\hline & & education & \\
\hline & & equal member in healthcare team & \\
\hline & & nursing expert & \\
\hline & & knowledge & \\
\hline & & responsibility & $\begin{array}{c}\text { knowledge and understanding of nursing role, } \\
\text { ethic }\end{array}$ \\
\hline & & competences & \\
\hline \multirow{11}{*}{ 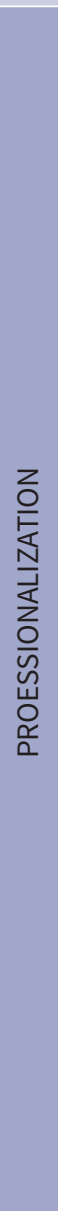 } & \multirow{11}{*}{ 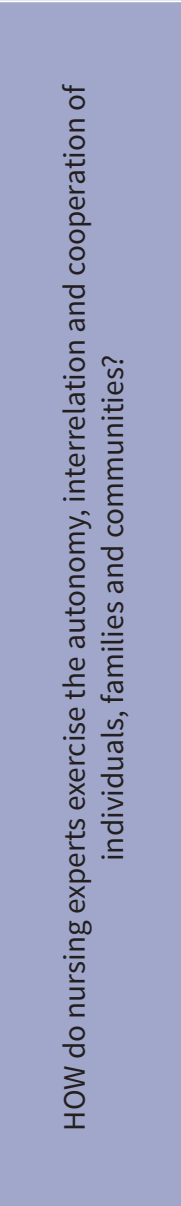 } & \multicolumn{2}{|c|}{ POSITIVE EXPERIENCES } \\
\hline & & cooperation with other fields & \\
\hline & & lifelong learning & \\
\hline & & autonomy & $\begin{array}{c}\text { identifying needs, } \\
\text { planning, } \\
\text { implementation of nursing, } \\
\text { decision-making, } \\
\text { leadership, } \\
\text { independent work in healthcare team, } \\
\text { supervision of work }\end{array}$ \\
\hline & & competences & $\begin{array}{l}\text { autonomous decision-making } \\
\text { recognition by society, } \\
\text { reputation in society }\end{array}$ \\
\hline & & quality of nursing & $\begin{array}{c}\text { research, } \\
\text { evidence based practice, } \\
\text { management of the patient and recovery }\end{array}$ \\
\hline & & responsibility & $\begin{array}{l}\text { nursing implementation, } \\
\text { leadership }\end{array}$ \\
\hline & & law regulation & responsibility \\
\hline & & education & $\begin{array}{l}\text { learning, } \\
\text { competences }\end{array}$ \\
\hline & & ethical values & $\begin{array}{l}\text { nursing implementation, } \\
\text { leadership }\end{array}$ \\
\hline & & knowledge & $\begin{array}{l}\text { nursing implementation, } \\
\text { leadership, } \\
\text { knowledge transfer in clinical practice, } \\
\text { jurisdiction in healthcare team, } \\
\text { autonomy in healthcare team }\end{array}$ \\
\hline
\end{tabular}

Source: Starc, 2011: 238

\section{Analysis of positive experiences}

The qualitative analysis of the principal item "Who is the nursing expert?" shows seven (7) categories: competences; cooperation with other professionals; equal cooperation in the healing and rehabilitation process; autonomy in decision-making (subcategories: responsibility, independent performance): experts/professionals; equal cooperation (equal member) in the healthcare team and knowledge (subcategories: professional knowledge and ethics). 


\section{Table 4. Summary of the results of the qualitative analysis and a list of the categories of the} semi-structured interview

\begin{tabular}{|c|c|}
\hline Main item & Categories \\
\hline \multirow{13}{*}{ 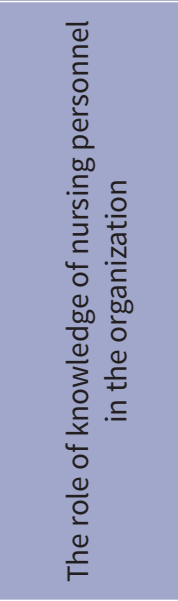 } & TOP MANAGEMENT \\
\hline & education as a permanent objective \\
\hline & simulations \\
\hline & the head of the outpatient clinic is a doctor \\
\hline & no independent human resource \\
\hline & PROFESSIONAL MANAGEMENT \\
\hline & knowledge acquisition \\
\hline & expertise \\
\hline & recruitment \\
\hline & knowledge transfer \\
\hline & autonomous areas: preventive medicine, diabetic outpatient clinic \\
\hline & not completely independent \\
\hline & sense of initiative \\
\hline \multirow{8}{*}{ 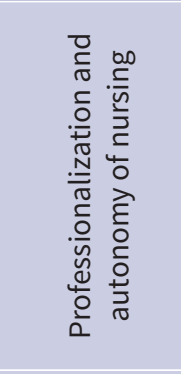 } & TOP MANAGEMENT \\
\hline & influence on the development of health organizations \\
\hline & financial constraints \\
\hline & simulations \\
\hline & nursing staff is quicker \\
\hline & PROFESSIONAL MANAGEMENT \\
\hline & autonomous areas: preventive medicine, diabetic outpatient clinic \\
\hline & knowledge is a prerequisite \\
\hline \multirow{10}{*}{ 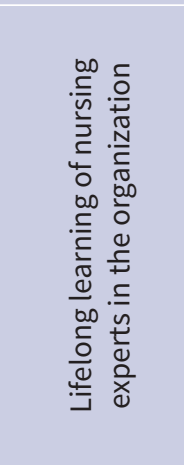 } & TOP MANAGEMENT \\
\hline & education is highly rated \\
\hline & realizing lifelong learning \\
\hline & education is extra motivated \\
\hline & PROFESSIONAL MANAGEMENT \\
\hline & more desire than resources \\
\hline & insufficient financial support of studies \\
\hline & in some form by the municipality \\
\hline & there are no targets for lifelong learning \\
\hline & no reward, no financial assets \\
\hline \multirow{6}{*}{ 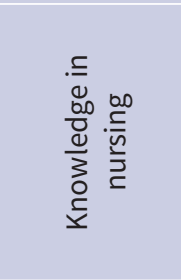 } & TOP MANAGEMENT \\
\hline & The acquisition of knowledge represents the acquisition knowledge \\
\hline & adaptation \\
\hline & PROFESSIONAL MANAGEMENT \\
\hline & knowledge is important \\
\hline & adaptation is very important \\
\hline \multirow{7}{*}{ 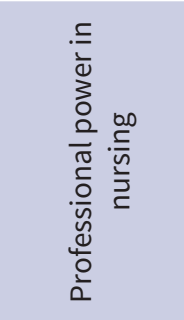 } & TOP MANAGEMENT \\
\hline & independence of the discipline \\
\hline & professional attitude towards work \\
\hline & competences \\
\hline & PROFESSIONAL MANAGEMENT \\
\hline & autonomy in their field \\
\hline & community nursing and healthcare education \\
\hline
\end{tabular}


The main item correlates to a nursing expert who equally cooperates with other professionals in the healing and rehabilitation process, based on professional knowledge (Fig. 2).

\subsubsection{Nursing expert in the healthcare team}

\section{Analysis of negative experiences}

The negative experiences suggest the non-equality and subordinate position of nursing experts, derived from nursing experts themselves. The aetiology of the problem most probably derives from their own historical and ideological beliefs and cultural transition of past social impacts.

\section{Analysis of positive experiences}

The qualitative analysis of the main item "How do nursing experts equally participate in the healing and rehabilitation process?" shows eleven (11) categories: jurisdiction; knowledge; competences; independent performance in a healthcare team (subcategories: equal expert); independent performance of nursing procedures; knowledge upgrade (subcategories: ethics); cooperation in healing and rehabilitation process (subcategories: benefit, ethics); independent decision-making; equal participation in the healthcare team.

The qualitative analysis of how the nursing experts equally participate in the healing and rehabilitation process correlates to nursing experts who equally participate in the healing and rehabilitation process, based on knowledge, jurisdiction and competences. Nursing experts independently perform nursing procedures and make decisions (Fig. 3).

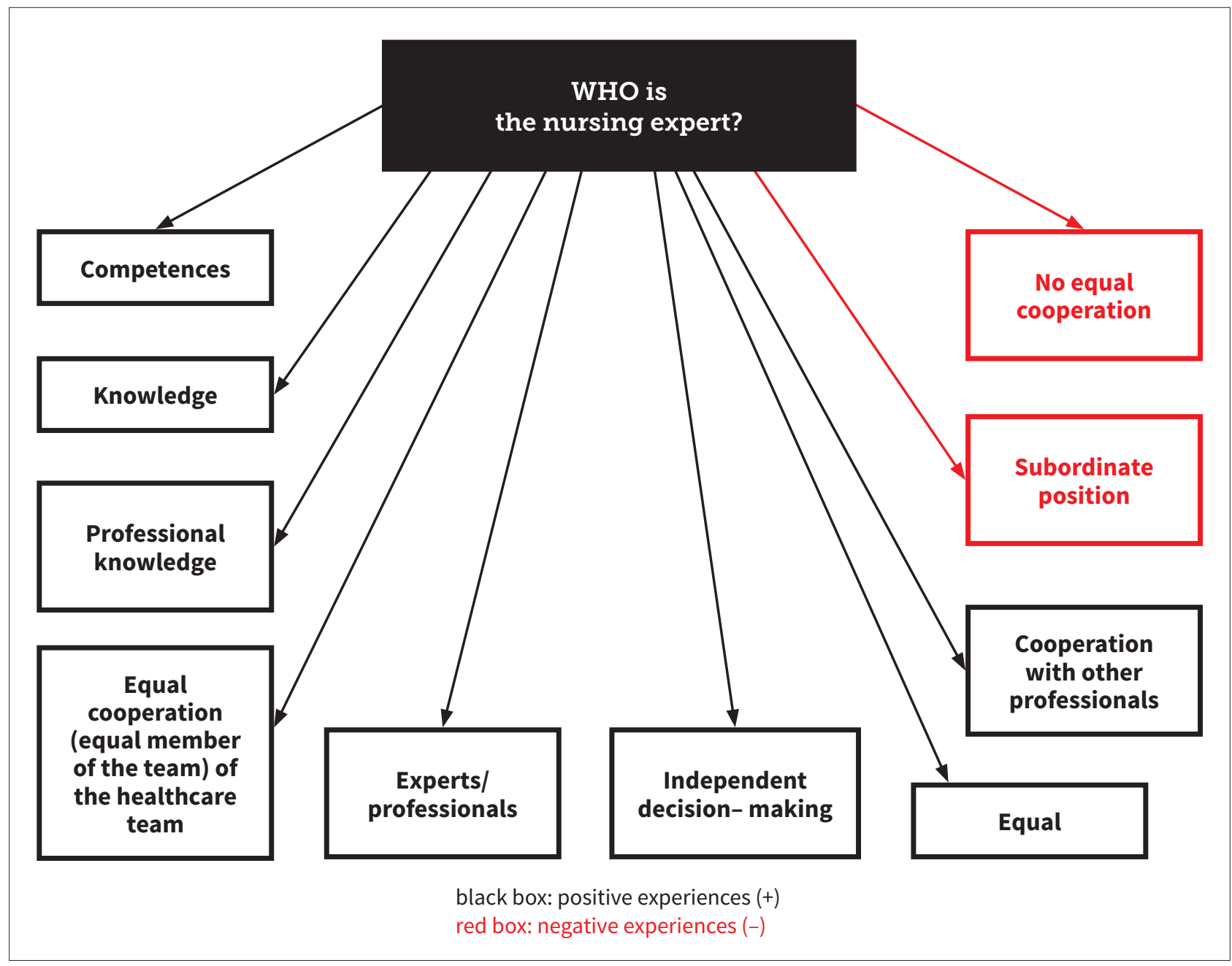

Figure 2. Nursing expert

Source: Starc, 2011: 243. 


\subsubsection{Nursing professionalization}

\section{Analysis of negative experiences}

The statement (in red) may indicate the bureaucracy in nursing. The cause could lie in the requirement of extensive and detailed plan of the nursing process, evaluation and work itself.

\section{Analysis of positive experiences}

The qualitative analysis of the main item "WHAT is professionalization of nursing?" shows ten (10) categories: lifelong learning (subcategories: social relations, work quality); competences (subcategories: social-needs satisfaction, independent decision-making, research, socialization of nursing experts); monopoly of activities, acquisition of supervision function (subcatego- ries: quality treatment of the patient, ethical aspect); education (subcategories: establishing standards, rules and work control); knowledge (subcategories: ethical aspect, professionalism, social-needs satisfaction, patient satisfaction, knowledge application into practice); patient (subcategories: responsibility acquisition), legally defined operation (subcategories: confidence); education; independence in nursing (subcategories: knowledge in nursing, cooperation in the healing and rehabilitation process, leadership, responsibility).

The quality analysis demonstrated that the professionalization in nursing correlates to nursing autonomy. We defined the concepts of knowledge, education, competencies and lifelong learning in nursing. Based on legal definition, professionalization means the monopoly of activity for the acquisition of control functions (Fig. 4).

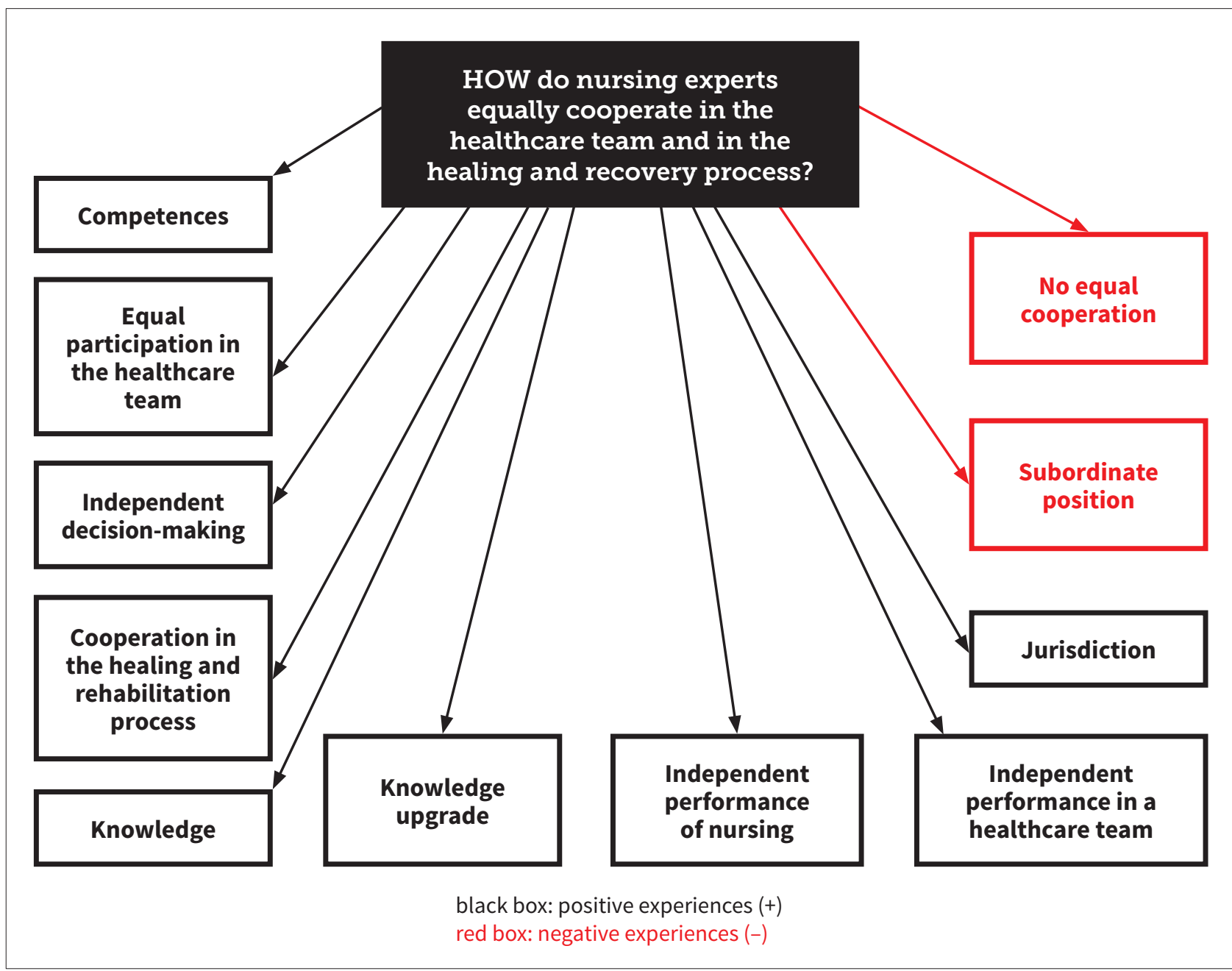

Figure 3. Cooperation of nursing experts in a healthcare team

Source: Starc, 2011: 245 


\subsubsection{The role of a nursing expert}

Analysis of negative experiences

The negative experiences show the misconception that nursing experts are only those who are "confirmed" as such by doctors and not by the profession itself.

Analysis of positive experiences

The qualitative analysis of the main item "Who is the nursing expert and who carries out the advocacy in nursing, promotes a safe environment, conducts research, participates in the formulation of healthcare policy and management of the healthcare systems and education" shows seven (7) categories: independent performance of nursing procedures (subcategories: patients' needs, independence in the management and administration of nursing care); education; equal member in the heal- ing and rehabilitation process; expert in nursing; knowledge; responsibility (subcategories: knowledge and understanding of the role of the nursing expert, ethics) and competences.

The acquired knowledge and competences are linked to nursing experts who independently and responsibly implement nursing; they are an equal member in the healing process (Fig. 5).

\subsubsection{Nursing experts independently exercise and operate in the healing and rehabilitation process}

\section{Analysis of negative experiences}

Negative perceptions may indicate the non-recognition of the profession, derived from members of nursing

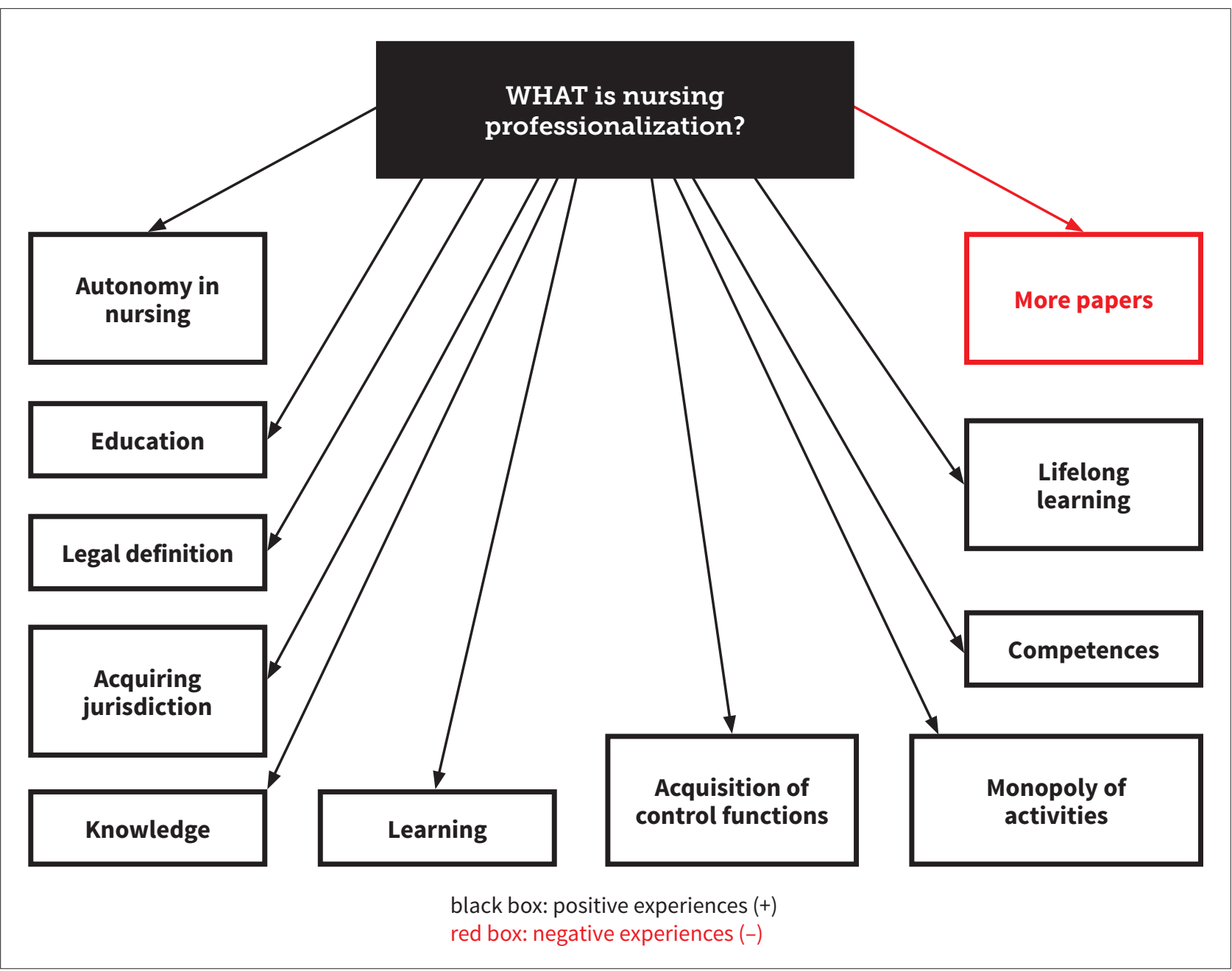

Figure 4. Professionalization of nursing 
themselves. The aetiology can be explained again as a result of past ideological beliefs of the nursing members and the historical socio-cultural influences.

\section{Analysis of positive experiences}

The quality analysis of the main item "How do nursing experts exercise independent, interdependent and cooperative treatment and encourage the participation of individuals of all ages, families, groups and communities, sick and healthy in all environments shows ten (10) categories: cooperation with other fields; lifelong learning; independent performance (subcategories: identifying needs, planning, performance of nursing care, decision-making, leadership, independent performance within a team, control); competences (subcategories: independent decision-making within their work, social recognition and reputation), nursing quality per- formance (subcategories: research, evidence-based practice, management of the patient and rapid recovery); responsibility (subcategories: implementation of nursing care, leadership); legal regulation (subcategories: responsibility); education (sub-categories: education, competences), ethical values (subcategories: implementation of nursing care, leadership); knowledge (subcategories: implementation of nursing leadership, knowledge transfer into clinical practice, independent jurisdiction in healthcare team, independence in healthcare team).

The quality analysis of the main item correlates to nursing experts who, based on knowledge, ethical values, learning, lifelong learning, independence, competencies, responsibility, legal regulations and with the cooperation with other fields, implement the quality, in-

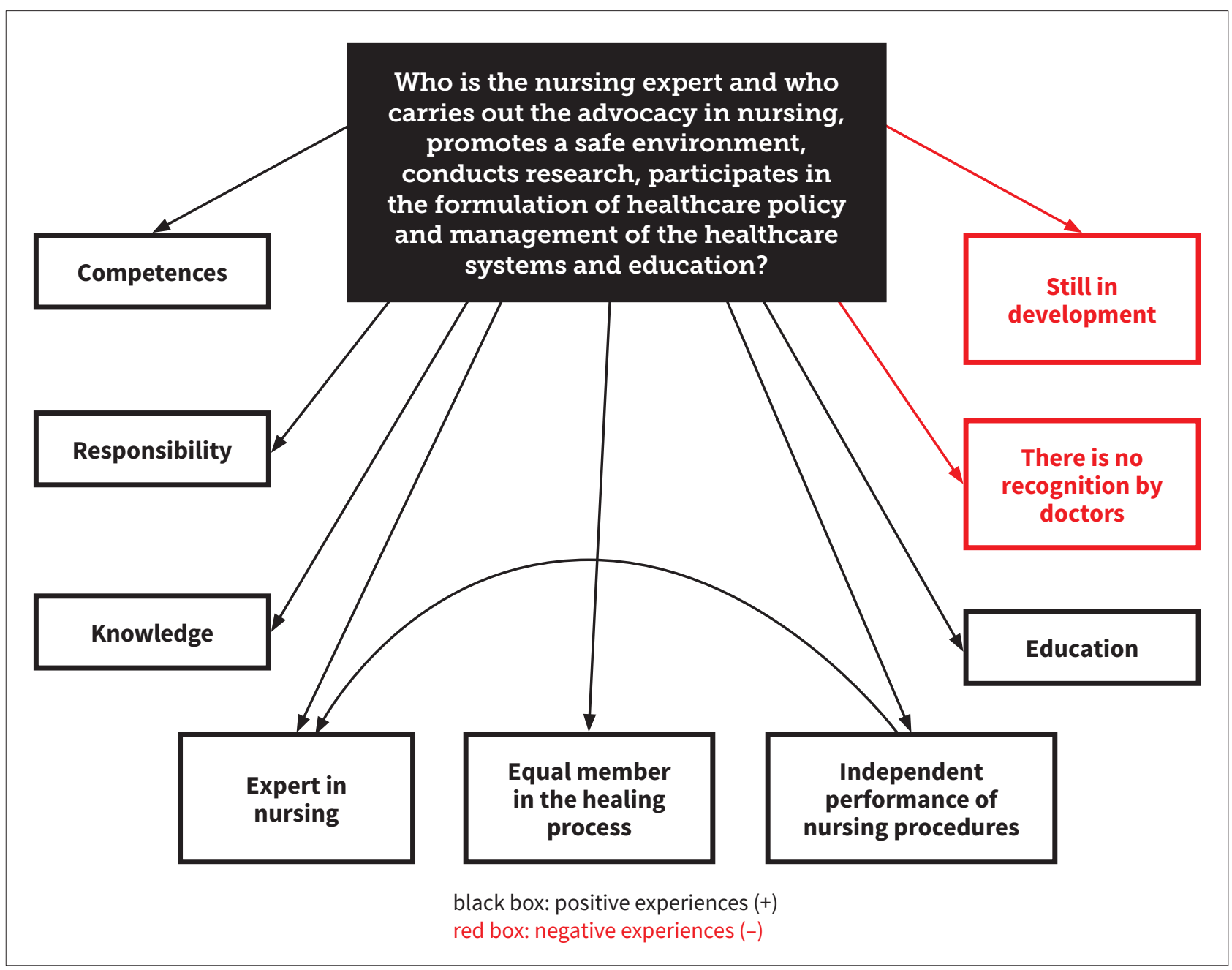

Figure 5. The role of a nursing expert

Source: Starc, 2011: 249 
dependent, interdependent and cooperative treatment and encourage the participation of all individuals, families and communities in all environments (Fig. 6).

\subsubsection{Structured interviews - quality analysis}

The role of the nursing expert knowledge within healthcare organization: the top level management shows five (5) categories: education as a permanent objective, stimulation, relative separation, the head of the outpatient clinic/clinic is a doctor and there is no independence in nursing. The level of professional management shows seven (7) categories: knowledge acquisition, expertise, knowledge transfer, autonomous areas: prevention in healthcare; outpatient clinic/clinic for diabetics, no autonomy in undertaking initiatives.
The quality analysis shows that the main item linked to the importance of knowledge in healthcare organizations, acquisition of professional knowledge and its transfer into practice. Knowledge contributes to the validation of the individual. On the other hand, the role of nursing expert knowledge in healthcare organizations is not clearly defined.

Professionalization and autonomy of nursing: the professionalization and the autonomy of nursing in healthcare organizations depend on financial resources. However, the professionalization and the autonomy in nursing are not clearly defined. Results of the interviews indicate that the respondents did not clearly recognize the concept of nursing professionalization.

Lifelong learning of nursing experts within healthcare organizations: nursing experts commit to lifelong learn-

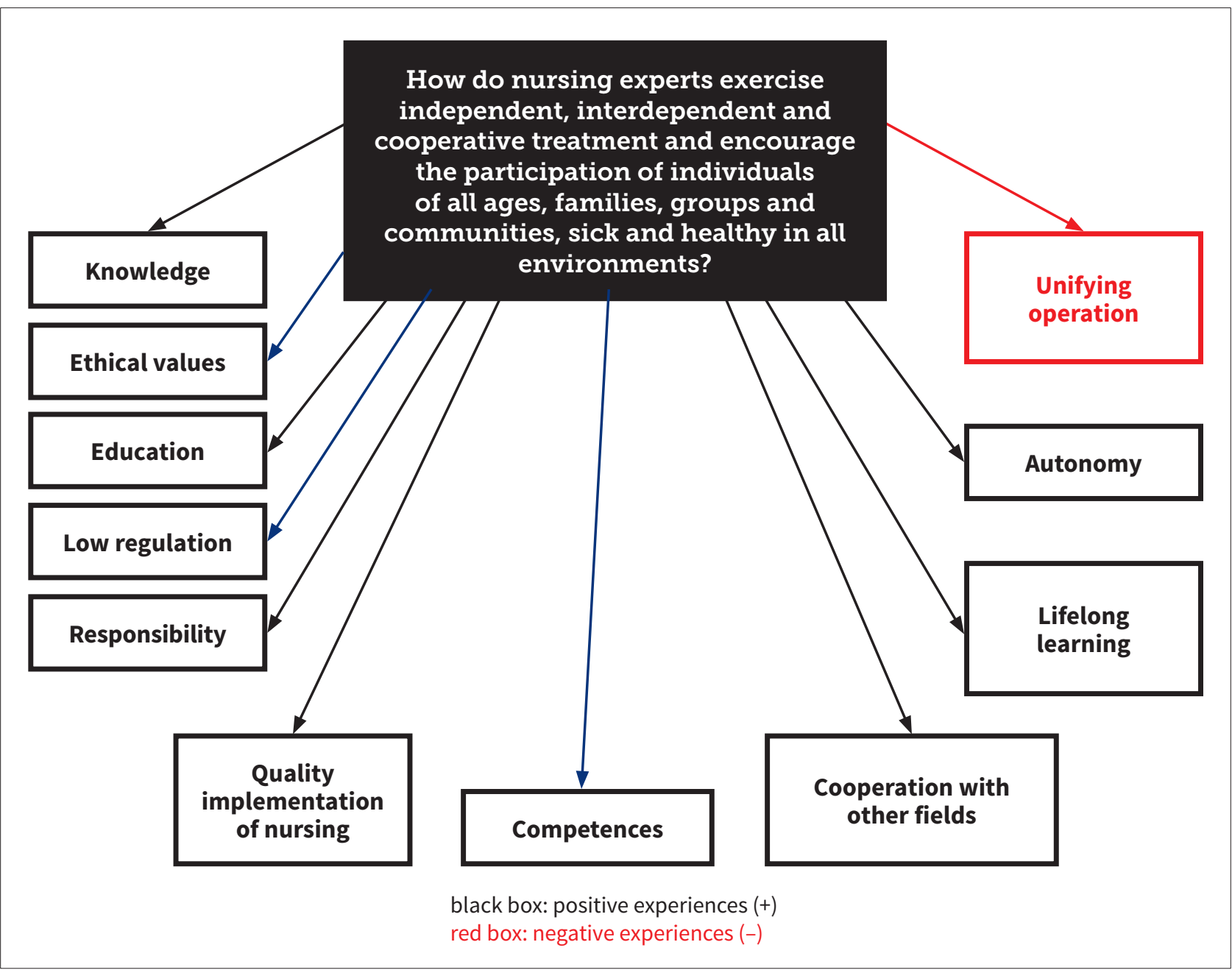

Figure 6. Nursing experts exercise the independent, interdependent and cooperative treatment Source: Starc, 2011: 251 
ing. However, the financial restrictions in nursing result in limitations of the investments in lifelong learning.

Knowledge in nursing: it represents one of the conditions which enables nursing experts to successfully adapt to workplace requirements.

Professional power in nursing: it refers to competition, influencing the professional relationships at workplace and independence of nursing.

\subsection{Verification of the impacts on nursing professionalization - the regression model}

The empirical findings (quantitative and qualitative analysis) helped to define four (4) elements of professionalization: lifelong learning, professional autonomy, knowledge, and the marginal positive impact of ethics in nursing. The major impact on professionalization was identified in nursing experts aged 41 years and over, with more than 26 years of work experience (Fig. 7)

\section{Discussion}

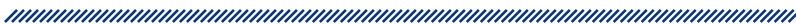

\subsection{Concept of professionalization in nursing}

The concept of nursing is determined by the following basic characteristics: knowledge, power and ethics (Abbott 1988). In nursing those characteristics could be the base/source for acquisition of a professional position, reputation and power and for the acquisition of professional surveillance. It could also be defined as a process of complex decision-making, which contributes to competition and encourages the professional control over the market and within healthcare organizations ${ }^{17-22}$. Finally, it could also be understood as a political process, whereby the members of professional groups make efforts for control over the services and, consequently, for self-regulation ${ }^{23}$. This concept includes a) nursing experts who, based on nursing knowledge, independently make decision and b) healthcare organizations, in which the profession (nursing) is conceived as a body of knowledge.

The first group includes observations for nursing professionalization: power for professional decision-making, ethical values and knowledge and lifelong learning. In particular, the knowledge which allows highest adapt-

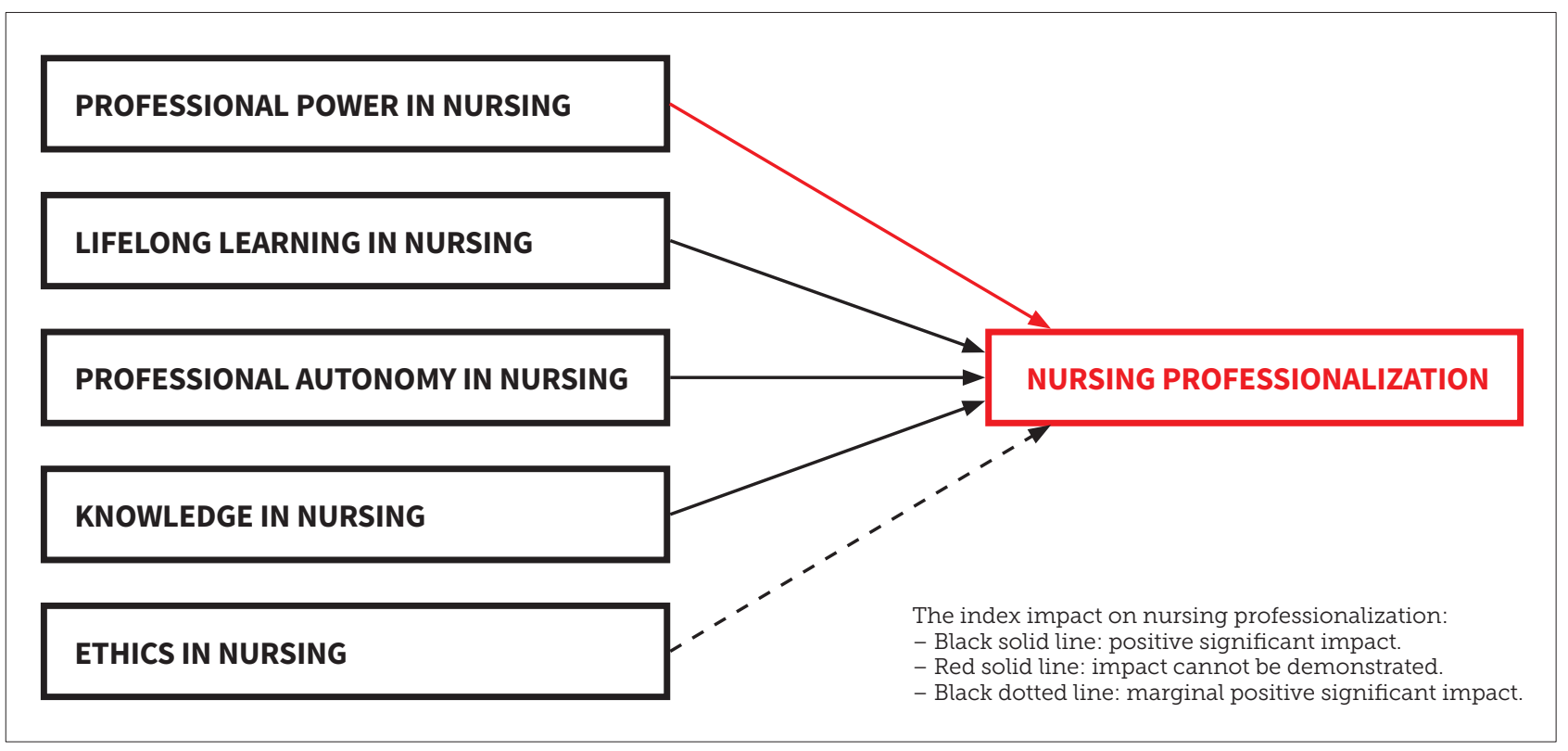

Figure 7. The regression model of causality of professionalization in nursing 
ability and innovativeness at a work place, contributes to the independence, source of progress in nursing and represents the ability to define a situation and consequently to act.

The second group includes healthcare organizations, in which the profession (nursing) is conceived as a body of knowledge.

Based on the quantitative and qualitative analysis, we can presume that the nursing experts are conscious of all three professionalization characteristics ${ }^{24}$ : knowledge, power and ethics.

\subsection{The concept of knowledge in nursing}

The concept of knowledge in nursing requires both the acquisition and implementation of new knowledge with scientific and professional human capital. In everyday clinical practice the nursing experts are supposed to be able to (a) link the theory and practice and (b) engage in research (be able to use new linkages with concepts). At the forefront, a new concept of "new nursing" emerges, which is based on the abandonment of organization as a task and introduces a greater role of the patient, cooperation between professions and evidence-based practice ${ }^{24-25}$. The concept of knowledge in nursing includes three basic characteristics: knowledge, combination of theory and practice and new links between the concepts.

The concept of knowledge in nursing is defined as an element of nursing professionalization. Nursing experts link the contents of knowledge with nursing professionalization. This is the knowledge which contributes to the adaptability and innovativeness at workplace, contributes to independence, and presents the source of progress, an added value in nursing and the ability to define the situation, and hence the appropriate act. On the other hand, in the healthcare organizations the role of knowledge is not clearly defined, which consequently leads to their dissatisfaction.

\subsection{The concept of professional autonomy}

Professions can achieve independence in various segments and aspects of work. The medical and nursing professions do not have an equal level of autonomy. The fact is that medical profession have an economic and political autonomy and the autonomy to construct standards and control the clinical practice ${ }^{26-27}$. The concept of professional autonomy identifies three distinct aspects, namely, the economic, political and clinical autonomy. Nursing experts consider the professional autonomy as an autonomy of nursing, with educated, independent and responsible nursing experts possessing the necessary competences, and who comply with the code of ethics of their profession. They function as equal members of a healthcare team, in their endeavour to satisfy the patients' needs.

\subsection{The concept of lifelong learning}

One of the factors of successful acquisition and development of human capital is the integration of nursing experts in lifelong learning. Lifelong learning should be understood as an achievement of objectives, both for individuals and organization at the same time. This means that with active support of top management of healthcare organizations, lifelong learning of professional management members and nursing experts is oriented towards greater efficiency of nursing and provision of the optimum for the health of the population. In relation to lifelong learning two dimensions should be noted. The first dimension is the lifelong learning which contributes to the nursing experts' acquisition of new knowledge which corroborates with the views of Altschul ${ }^{28}$ and Jarvis ${ }^{29}$. The second dimension is characterized by four basic features:

- involvement of nursing experts in lifelong learning,

- achieving the objectives for individuals and the organization at the same time,

- achieving greatest effectiveness in nursing,

- ensuring optimal health conditions.

\subsection{The concept of professional power in nursing}

The power to make decisions in nursing lies in their professional power. In general, the professional power allows the creation of the basis for the formal organization and supervision or the legal right to verify the entry conditions, education and training of the nursing personnel and their licensing.

The professional power is a characteristic which supports the establishment of professional autonomy. In other words, professional power is an attribute of selfregulation and control over the practice. The professional power of nursing experts comprises two dimensions. Firstly, it is linked to individuals or a professional group, and secondly, to certain social roles. 


\subsection{The concept of ethics in nursing}

The concept of ethics in nursing defines the ethical aspect in relation to the experts and clients/patients. The key assumptions of efficacious professionalization represent the professional strategy within the educational system and knowledge.

\section{Conclusions and recommendations}

Research findings lead to conclusions and recommendations, which are focused on nursing experts in healthcare organizations:

- Increased financial investment in lifelong learning of nursing experts at the secondary and tertiary level of healthcare should contribute to the increased number of passive and/or active participants in education and learning.

- The value of knowledge of nursing experts in healthcare organizations is twofold. Knowledge acquisition contributes to the growth of scientific and professional human capital and subsequently also contributes to the development of intellectual capital of healthcare organizations.

- Healthcare organizations are supposed to ensure the uniform distribution of knowledge and critical mass. This means that the highest active potential of knowledge increases the intellectual capital of healthcare organizations ${ }^{30-33}$. Healthcare organizations should be based on organizational knowledge (learning from each other) which fosters the creation and exchange of new knowledge. The newly acquired knowledge represents a competitive advantage for individuals and adaptability of healthcare organization.

\section{References}

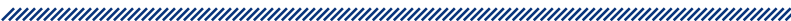

1. Hampton D, Hampton G. Professionalism and the nursemidwife practitioner: an exploratory study. Journal of the American Academy of Nurse Practitioners. 2000;12(6): 218-25.

2. Turner B. Medical Power and Social Knowledge. 2nd Edition. London, Thousand Oaks, New Delhi: SAGE Publications, 1995.

3. Coburn D, Willis E. The Medical Profession: Knowledge, Power, and Autonomy. In: Albrecht G, Fitzpatrick R, Scrimshaw S. The Handbook of Social Studies in Health \& Medicine. London, Thousand Oaks, New Delhi: SAGE, 2003.

4. Hugman, R. Power in caring professions. Houndmills, Basingstoke. London: Macmillan, 1991.

5. Giddey M. Institutions, individuals and professional power. In: Moon G, Gillespie R. Society and Health. An Introduction to social science for health professionals. London, New York: Routledge, 1995.

6. Gabe J, Bury M, Elston M. Key Concepts in Medical Sociology. London, Thousand Oaks, New Delhi: Sage Publications, 2004.

7. Starc A, Kos Grabnar E, Požun P. Predstavitev podlag specializacije v zdravstveni negi Slovenije. In: Dvoršak Majcen J. et al. 7. Konres Zdravstvene in babiške nege Slovenije. Ljubljana: Zbornica zdravstvene in babiške nege Slovenije, 2009:1-8.

8. Schultz, TW. Resources of HigherEducation:AnEconomist's View. The Journal of Political Economy. 1968;76(3):327-347.

9. Simon $\mathrm{H}$. Bounded rationality and organizational learning. Organization Sciences. 1991;2(1);125-34.

10. Civi E. Knowledge management as a competitive asset: A review. Marketing Intelligence \& Planning. 2000; 18(4):166-174

11. Bierly PE, Daly P. Aligning Human Resource Management Practices and Knowledge Strategies. In: Choo CW, Bontis N. The Strategic Management of Intellectual Capital and Organizational Knowledge. Oxford: Oxford University Press, 2002: 277-295.

12. Wong K, Aspinwall E. Characterizing knowledge management in the small business environment. Journal of Knowledge Management. 2004; 8(3):44-61.

13. Starc A, Ilič B. Pridobivanje in razvoj znanstvenega in strokovnega človeškega kapitala v zdravstveni negi: študija primera. Obzor Zdravstne Nege. 2007;41(2/3):61-9.

14. Starc A. Nursing Professionalism in Slovenia: Knowledge, Power, and Ethics. Nursing Science Quarterly. 2009;22(4):371-74.

15. Starc A. Identification of nursing professionalization elements in Slovenia. Doctoral dissertation. Ljubljana: University of Ljubljana, 2011.

16. Starc A, Pahor M, Ilič B. What makes nursing a profession: professionalization elements. Health Med. 2012;6(11):38153821. 
17. Durkheim E. Professional Ethics and Civic Morals. London: Routledge; 1992.

18. Turner, BS. Medical Power and Social Knowledge. 2nd ed. London, Thousand Oaks, New Delhi: SAGE Publications, 1995.

19. Dingwall R. Professions and Social Order in a Global Society. Revista Electrónica de Investigación Educativa. 2004;6(2):1-16.

20. Freidson E. Professionalism Reborn: Theory, Prophecy and Policy. Cambridge: Polity, 1994.

21. Freidson E. Professionalism: The Third Logic. London: Polity, 2001.

22. Parkin P. Nursing the future: a re-examination of the professionalization thesis in the light of some recent developments. Journal of Advanced Nursing. 1995;21:561-567.

23. Abbott AD. The System of Professions: An Essay on the Division of Expert Labour. Chicago: University of Chicago Press, 1988

24. Marrs JA, Lowery LW. Nursing Theory and Practice: Connecting the Dots. Nursing Science Quarterly. 2006;19(1):44-50.

25. Walby S, Greenwell J, Mackay L, Soothill K. Medicine and Nursing. Professions in a Changing Health Service. London, Thousand Oaks, New Delhi: SAGE Publications, 1994.
26. Marrs JA, Lowery LW. Nursing Theory and Practice: Connecting the Dots. Nursing Science Quarterly. 2006;19(1):44-50.

27. Nettleton S. The Sociology of Health and IIIness. Cambridge, Oxford: Polity Press, 1995.

28. Gabe J, Bury M, Elston MS. Key Concepts in Medical Sociology. London, Thousand Oaks, New Delhi: Sage Publications, 2004.

29. Altschul A. How far should further education go? Nurses Mirror. 1982;155(1):29-30.

30. Jarvis P. Lifelong learning and its relevance to nursing. Nursing Education Today. 1987;7(2):655-660.

31. Carayannis E, Jeffrey A. The wealth of knowledge: converting intellectual property to intellectual capital to competitive research and technology management settings. 1999. [Internet] Available from: http://www. uni-klu.ac.at/wiho/downloads/CARAYANNIS_IPR_IJTM. pdf (accessed 28 Oct 2010).

32. Drucker P. The rise of the knowledge society. 1993. [Internet] Available from: http://search.epnet.com/login.aspx?dir ect=true\&db=aph\&an=9610291205 (accessed 25 Jun 2005).

33. Drucker P. Knowledge-worker productivity: the biggest challenge. In: Cortada, JW, Woods JA. The Knowledge Management Yearbook 2000-2001. USA: Butterworth-Heinemann; 1999:267-277. 


\section{PROFESIONALIZACIJA U LANCU ZDRAVSTVENE ZAŠTITE}

1 Andrej Starc

1 Zdravstvena fakulteta, Univerza v Ljubljani, Zdravstvena pot 5, 1000 Ljubljana, Slovenija

\section{Sažetak}

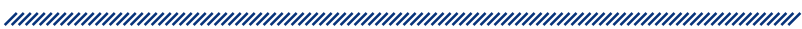

Uvod: Nekoliko čimbenika utječe na proces profesionalizacije. Rad se fokusira na proces profesionalizacije $u$ lancu zdravstvene zaštite. Poseban naglasak stavljen je na sestrinstvo i profesionalizaciju sestrinstva kao struke. Tijekom procesa tranzicije postoje određeni endogeni i egzogeni elementi koje je potrebno identificirati.

Metode: $U$ analizi podataka korištena je kvantitativna i kvalitativna metodologija. U kvantitativnom dijelu analize korištena je deskriptivna statistika, analiza kontingencije, metoda najmanjih kvadrata i multivarijatna linearna regresija sa i bez kontrolnih varijabli, oboje temeljenih na indeksaciji. Kvalitativni dio se sastojao od analize podataka prikupljenih putem otvorenih pitanja i polu-strukturiranog intervjua. Za potrebe istraživanja izrađen je i posebno prilagođen upitnik.

Rezultati: Značajke procesa profesionalizacije prisutne su kod profesionalaca u području sestrinstva starijih od 51 godina, s više od 26 godina radnog iskustva, i zaposlenih na primarnoj razini zdravstvene zaštite. Stjecanje novih znanja predstavlja doprinos njihovom ljudskom kapitalu te istovremeno podiže razinu njihovog stručnog znanja. Cjeloživotno učenje, autonomija sestrinskih profesionalaca i specifična znanja u sestrinstvu kao endogeni i egzogeni čimbenici ukazuju na statistički značajan pozitivan utjecaj. Analiza je utvrdila da etika u sestrinstvu ima samo marginalan statistički značajan pozitivan utjecaj u procesu profesionalizacije sestrinstva.

Zaključak: Identifikacija endogenih i egzogenih čimbenika omogućuje dodatno planiranje i istraživanje prakse i kvalitete zdravstvene zaštite.

Ključne riječi: proces profesionalizacije, zdravstvena zaštita, lanac zdravstvene zaštite, ljudski kapital 